\title{
Pengajuan dan Pemberian Hak Restitusi Bagi Anak Yang Menjadi Korban Kejahatan Seksual
}

\author{
Sapti Prihatmini, Fanny Tanuwijaya, Dina Tsalist Wildana, Misbahul Ilham \\ Fakultas Hukum, Universitas Jember \\ saptiprihatmini@yahoo.co.id
}

\begin{abstract}
This paper aims to analyze the mechanism for submitting and granting restitution as the responsibility of perpetrators of crimes. The restitution submission has been regulated in government regulations. However, the implementation of the restitution provision has not been fully implemented due to a lack of maximum assistance by the relevant government, such us fulfilling the rights of victims to obtain the restitution as a form of protection of children after the occurrence of a crime for the loss suffered by the victims. This study uses a doctrinal legal research, while the approach used is socio-legal as an effort to explore a problem by not only fulfilling the study of legal norms or doctrines, but also looking comprehensively at the context of norms and enforcement. The results showed that the submission of restitution stipulated in Government Regulation No. 43 of 2017 outlines that restitution is a compensation payment charged to the perpetrator based on a court decision. It has permanent legal force for material and immaterial losses suffered by the victim, as in the case of giving restitution for a non specifically regulated the period of payment and a rejection of payments from perpetrators of sexual crimes.
\end{abstract}

\section{Keywords: Legal Protection, Restitution, Children Who Become Victims of Crime.}

\begin{abstract}
Abstrak
Tulisan ini bertujuan untuk menganalisis terkait mekanisme pengajuan dan pemberian restitusi sebagai tanggungjawab pelaku untuk memenuhi hak anak yang menjadi korban tindak pidana. ketentuan pelaksana yang mengatur terkait pengajuan dan pemberian restitusi di atur dalam PP Nomor 44 Tahun 2008 dan PP Nomor 43 Tahun 2017. Namun bentuk implementasi dari pemberian restitusi yang menjadi hak anak (korban) belum sepenuhnya berjalan maksimal, diakibatkan kurangnya pendampingan secara maksimal oleh pemerintah terkait tahapan-tahapan pemenuhan hak korban untuk mendapatkan rehabilitasi, kompensasi dan restitusi sebagai bentuk perlindungan anak pasca terjadinya tindak pidana atas kerugian yang diderita anak dan atau pihak keluarga korban. Penelitian ini menggunakan penelitian doktrinal (doctrinal legal research), sedangkan pendekatan yang digunakan yaitu (socio-legal studies) sebagai upaya mendalami suatu masalah dengan tidak mencukupkan pada kajian norma atau doktrin hukum, melainkan pula melihat secara komprehensif konteks norma dan pemberlakuannya. Hasil penelitian menunjukkan bahwa pengajuan restitusi yang telah diatur dalam PP Nomor 43 Tahun 2017 mengartikan bahwa restitusi merupakan suatu pembayaran ganti kerugian yang dibebankan kepada pelaku berdasarkan putusan pengadilan yang berkekuatan hukum tetap atas kerugian
\end{abstract}


materiil dan immateriil yang diderita korban atau keluarganya, demikian dalam hal pemberian restitusi belum diatur secara khsusus jangka waktu pembayaran dan penolakan pembayaran dari pelaku kejahatan seksual.

Kata kunci: Perlindungan Hukum, Restitusi, Anak Yang Menjadi korban Tindak Pidana.

\section{Pendahuluan}

Selama ini kejahatan kekerasan seksual terhadap anak tidak hanya menjadi perbincangan dalam skala nasional, namun juga telah menjadi isu internasional baik dari segi upaya preventif dan upaya represif oleh suatu negara dalam melindungi anak sebagai korban kekerasan seksual. Dijelaskan dalam Pasal 1 ayat 2 Undang-Undang Nomor 35 Tahun 2014 Tentang Perubahan Atas UU No. 22 Tahun 2003 tentang Perlindungan Anak (Selanjutnya UU Perlindungan Anak), bahwa suatu perlindungan bagi anak merupakan segala kegiatan dalam upaya menjamin dan melindungi anak dan hak-hak yang dimiliki agar tetap hidup, tumbuh, berkembang, dan berpartisipasi, secara optimal sesuai dengan harkat dan martabat kemanusiaan, serta mendapat perlindungan dari kekerasan dan diskriminasi. Bentuk perlindungan terhadap korban tindak pidana dapat diberikan dalam berbagai cara baik dalam kategori kerugian materiil maupun immateriil.

Perlindungan yang tidak maksimal tidak hanya pada proses penegakan hukum oleh kepolisian serta instasi pemerintah yang lain, namun juga pada setelah pelaku kejahatan seksual pada anak dikenai hukuman atau telah melewati proses litigasi dalam pengadilan, korban (victim) cenderung diabaikan. Hal ini menandakan bahwa tidak ada upaya serius yang dapat dilakukan untuk lebih menekankan perhatian terhadap korban yang berstatus sebagai anak. Penelantaran secara fisik maupun psikis yang ditimbulkan akibat pelaku yang tidak bertanggungjawab berdampak pada banyaknya kasus kejahatan seksual yang tidak dapat diungkap oleh penegak hukum disebabkan oleh saksi dan korban tidak dapat memberikan keterangan. Meskipun dalam Undang-Undang Nomor 31 Tahun 2014 tentang Perubahan Atas Undang-Undang Nomor 13 Tahun 2006 tentang Perlindungan Saksi dan korban 
(Selanjutnya UU Perlindungan Saksi dan Korban) telah dijamin untuk memberikan rasa aman dalam memberikan keterangan saat proses pemeriksaan. Disisi lain, perwujudan dari rasa aman tersebut tidak berjalan sesuai dengan tujuan yang dimaksud. Akhirnya, korban lebih memilih untuk tidak bersuara dan lebih memilih diam.

Berkaitan dengan tanggungjawab tersebut dalam bentuk upaya melindungi anak tidak hanya dari aspek tanggungjawab dan kewajiban lembaga negara yang diberikan wewenang oleh pemerintah pusat maupun daerah, namun juga harus diperhatikan terkait tanggungjawab terhadap anak oleh orang tua dan keluarga berdasarkan UU Perlindungan Anak. (Renaldi P.Bahewa, 2016: 2).

Dalam upaya menjamin perlindungan anak, maka sangat penting untuk diperhatikan akibat terjadinya tindak pidana yang diderita anak, mengingat hal ini dapat menyebabkan seseorang mengalami kerugian dan penderitaan baik secara fisik, psikis maupun kerugian harta benda. Melalui peraturan perundang-undangan saat ini, jaminan perlindungan atas hakhak korban perlu mendapatkan kepastian hukum dan keadilan akibat terjadinya tindak pidana. Untuk tindak pidana pelanggaran hak asasi manusia yang berat korban perlu mendapatkan kompensasi dan bagi korban tindak pidana di luar pelanggaran hak asasi manusia yang berat perlu diberikan restitusi dan bantuan pemulihan terhadap kondisi fisik dan psikis sesuai dengan prosedur pengajuan dan pemberian hak-hak tersebut.

Melihat fakta yang ada, bahwa kekerasan yang sering terjadi terhadap anak dapat merusak, membahayakan kondisi psiko sosial dan menimbulkan rasa takut berkepanjangan akibat kejadian yang pernah di alami. Dalam hal ini, anak yang menjadi korban kekerasan jelas telah menderita kerugian, tidak saja bersifat matertial, tetapi juga bersifat immateriil seperti goncangan emosional dan psikologis, yang dapat mempengaruhi kehidupan masa depan anak. Bentuk-bentuk kekerasan yang sering terjadi pada anak. (Maidin Gulton, 2013:2). 
Namun, berbeda dengan tujuan dari adanya pemberian restitusi ini, dalam upaya perlindungan melalui pemenuhan haknya cenderung tidak berjalan dengan lancar setelah anak mengalami tindakan yang menyimpang, sehingga hak anak yang seharusnya terpenuhi menjadi terabaikan. Termasuk mekanisme pengajuan hak restitusi atau ganti rugi yang diderita anak akibat perbuatan pelaku. Proses yang tidak mudah serta literasi bagi pihak korban yang minim menjadikan kendala dalam mengupayakan hak restitusi yang seharusnya diterima anak.

Sebagai wujud implementasi penerapan norma yang terkandung dalam ketentuan yang mengatur bagaimana proses pengajuan dan pemberian hak restitusi dengan melihat norma, serta pemberlakuannya baik saat ini, maupun masa yang akan datang, sehingga hak restitusi yang telah mendapatkan perhatian khusus dengan memperhatikan asas dan tujuan dari upaya perlindungan anak dapat berjalan dengan optimal.
Beranjak dari uraian sebagaimana telah diuraikan diatas, bahwa dipandang perlu untuk dirumuskan permasalahan sebagai berikut :

1) Bagaimana Bentuk Perlindungan Anak dalam hal kerugian materiil dan immateriil yang diderita anak pasca terjadinya kejahatan?.

2) Bagaimana Pelaksanaan Pengajuan dan Pemberian Restitusi Bagi Anak Yang Mengalami Kekerasan Seksual di tinjau dari peraturan perundang-undangan yang berlaku?

\section{Metode Penelitian}

Penelitian ini menggunakan tipe penelitian doktrinal (doctrinal legal research) yaitu penelitian yang difokuskan untuk menganalisis penerapan kaidah atau norma dalam hukum positif dan menjadikan kaidah hukum abstrak sebagai ukuran kebenaran. Selain itu penelitian ini menggunakan pendekatan sosio-legal (socio-legal studies) sebagai upaya untuk menjajaki dan mendalami suatu 
masalah dengan tidak mencukupkan pada kajian norma atau doktrin hukum yang terkait, melainkan melihat secara lengkap konteks norma dan pemberlakuannya. Terakhir pendekatan konseptual (conseptual approach) yang berasal dari pengembangan pandangan dan doktrin yang dalam ilmu hukum. (Muhammad Helmy Hakim, 2016:108)

Sedangkan sumber yang digunakan yaitu sumber bahan hukum primer, bahan hukum sekunder, dan bahan non hukum. Penggunaan sumber tersebut sebagai alat untuk memecahkan isu hukum serta memberikan perskripsi yang seharusnya diperlukan. (Rikardo Simarmata, 2006 :10)sebagai metode analisis bahan hukum, penulis menggunakan analisis deduktif dengan melihat permasalahan secara umum kepada yang khusus untuk mencapai maksud sebenarnya.

\section{Langkah} selanjutnya mengidentifikasi fakta hukum dan menimalisir hal-hal yang tidak relevan untuk memecahkan isu hukum yang ditetapkan, pengumpulan bahan-bahan hukum dan non hukum yang dinilai relevan, melakukan pengkajian atas isu hukum yang diajukan berdasarkan bahan yang telah dikumpulkan, menarik kesimpulan dalam bentuk argumentasi dan jawaban atas isu hukum, serta memberikan preskripsi berdasarkan argumentasi yang dibangun dalam kesimpulan.

\section{Pembahasan}

\section{Perlindungan Terhadap Anak} Yang Menjadi Korban Tindak Pidana Kejahatan Seksual.

Telaah pada suatu tindakan yang sering dialami oleh anak adalah kejahatan kekerasan seksual, disamping itu juga terdapat bentukbentuk lain yang sering dialami oleh anak. Tindak pidana kejahatan seksual yang diterima anak merupakan suatu bentuk penyiksaan yang dilakukan orang dewasa maupun remaja sebagai bahan eksploitasi seksual dengan meminta ataupun menekan secara paksa kepada anak untuk melakukan hubungan seksual, dengan memperlihatkan hal-hal berbau pornografi kepada anak seperti kontak fisik dengan alat kelamin anak, melihat kelamin anak tanpa 
adanya kontak fisik serta menggunakan anak sebagai alat reproduksi pornografi anak. (Ario Ponco W, 2013 ; 2)

Dampak dari tindakan yang tidak wajar (kejahatan seksual) terhadap anak dapat menimbulkan beberapa reaksi termasuk stress, depresi, trauma psikologi dan sosial bersamaan dengan trauma kepanjangan yang menjadikan posisi anak terus merasakan kejadian yang pernah dialami hingga dewasa. Proses penyembuhan akibat trauma mental yang diderita anak sangat sulit untuk di rehabilitasi karena ingatan yang ada pada anak cenderung lebih kuat, sehingga peristiwa ini seharusnya dapat dicegah terjadinya oleh orang tua, masyarakat serta lembaga yang memiliki kewenangan dalam hal perlindungan terhadap anak.

Ditinjau dari bentuk perlindungan terhadap anak di Indonesia, terdapat beberapa Lembaga yang dikhususkan berdasarkan kewenangan yang diatur oleh Undang-Undang dalam hal memberika bantuan baik pendampingan hukum, psikologi serta upaya rehabilitasi terhadap anak yang menjadi korban tindak pidana, yaitu Komisi Perlindungan Anak (Pusat) , Lembaga Perlindungan Anak (Daerah) dan Lembaga Pendampingan yaitu Lembaga Perlindungan Saksi dan Korban. Demikian dengan hak anak yang telah di jamin dalam UU Perlindungan Anak yang menyebutkan bahwa hak anak merupakan bagian dari hak asasi manusia yang wajib dijamin, dilindungi dan dipenuhi oleh orang tua, keluarga, masyarakat, negara, pemerintah, dan pemerintah daerah. Sebab itu perlindungan yang dimaksud merupakan segala kegiatan untuk menjamin dan melindungi anak dan hak-hak yang dimiliki agar tetap hidup, tumbuh, berkembang, dan berpartisipasi secara optimal sesuai dengan harkat martabat kemanusiaan, serta mendapatkan perlindungan dari kekerasan serta diskriminasi. ( Pasal 1 (2) UU Nomor 35 Tahun 2014).

Jaminan Perlindungan terhadap Anak oleh negara di bagian kedua UU Perlindungan Anak mengenai kewajiban dan tanggungjawab 
Negara, Pemerintah dan Pemerintah

Daerah bersama-sama melindungi dan memenuhi hak anak, diatur dalam pasal 21 sampai dengan pasal 24 yang berisikan mengenai penghormatan terhadap hak anak tanpa ada diskriminasi, membuat kebijakan yang berkaitan dengan anak, mengupayakan kota layak anak, adanya dukungan sarana prasarana, dan ketersediaan sumber daya manusia dalam penyelenggaraan perlindungan anak serta menyampaikan kepada anak terkait hak yang dimiliki. Seperti, menyampaikan pendapat di muka umum sesuai dengan usia dan kecerdasan anak. Sedangkan Jaminan Perlindungan dari Masyarakat juga diatur dalam Pasal 25 UU Perlindungan Anak menitikberatkan pada peran masyarakat dalam penyelenggaraan perlindungan terhadap anak melalui partisipasi dan keterlibatan organisasi kemasyarakatan, akademisi dan pemerhati anak sesuai dengan kemampuan yang dimiliki.

Demikian dengan tanggung jawab orang tua dan keluarga sebagai bentuk jaminan perlindungan yang lebih dominan dalam hal memberikan pembinaan, pembimbingan dan pengamalan ajaran agama bagi anak, penekanan pada tanggungjawab serta kewajiban orang tua dan keluarga dikarenakan kedekatan hubungan secara lahiriah antara orang tua, keluarga dan anak.Lebih khusus,Indonesia secara nasional telah mengupayakan adanya bentuk jaminan perlindungan terhadap anak dengan meratifikasi protokol opsional konvensi hak-hak anak mengenai penjualan anak, prostitusi pada anak, dan pornografi anak dan telah di sahkan dalam hokum positif nasional melalui UU Nomor 10 Tahun 2012 tentang Pengesahan optional protocol to the convention on the rights of the child on the sale of children, child prostitution and child pornography (protokol opsional konvensi hak-hak anak mengenai penjualan anak, prostitusi anak, dan pornografi anak.

Disahkannya protokol ini diakibatkan keprihatinan akan bertambahnya bentuk-bentuk pornografi anak di internet dan teknologi yang telah berkembang pesat sehingga mudahnya 
pendistribusian serta pentrasmisian pornografi anak di dunia digital, hal ini juga mengingat pada konferensi Internasional mengenai upaya memerangi pornografi pada anak di dunia digital ( Konvesi Wina, 1999) serta lebih lanjut mengenai kesimpulan atas konferensi tersebut yang menyerukan kriminalisasi mendunia atas produksi, distribusi, ekspor, pemindahan, impor , kepemilikan pribadi, dan periklanan pornografi anak, serta menekankan kerjasama yang lebih kuat melalui kemitraan antara pemengang otoritas suatu negara dengan industri layanan internet.

Suatu jaminan perlindungan terhadap anak harus tetap memperhatikan asas-asas serta tujuan perlindungan anak, menurut arif gosita, terdapat beberapa hal yang perlu diperhatikan mengenai perlindungan anak yang berhubungan dengan suatu perkara seperti korban (anak) berhak untuk mendapatkan kompensasi atau restitusi atas penderitaannya yang sesuai dengan kemampuan pelaku berdasarkan taraf keterlibatan, partisipasi dan peran korban terjadinya suatu tindak pidana atau penyimpangan yang dilakukan oleh pelaku. Disamping itu anak (korban) berhak mendapatkan pembinaan serta rehabilitasi, serta mendapatkan perlindungan dari ancaman pihak pelaku apabila korban melaporkan atau memberikan keterangan di muka persidangan sebagai saksi. Tidak hanya itu, korban (anak) berhak mendapatkan bantuan hukum serta pendampingan oleh Lembaga yang berwenang dan dapat melakukan upaya hukum yang telah ditentukan berdasarkan peraturan perundangundangan.(Lilik Mulyadi, 2010 ; 19).

Berkaitan dengan bentuk perlindungan yang telah dijamin dalam UU Perlindungan Anak, ditinjau secara substantial telah memenuhi standar perlindungan terhadapan anak serta telah memberikan perlindungan khusus terhadap anak yang menjadi korban dari kekerasan seksual. Hal tersebut dimuat dalam perlindungan khusus terhadap anak dalam pasal 69 A UU Perlindungan Anak melalui pemberian edukasi tentang kesehatan reproduksi, nilai agama, dan nilai kesusilaan, mendapatkan rehabilitasi 
sosial secara utuh, mendapatkan pendampingan psikososial pada saat pengobatan sampai dengan pemulihan dan pemberian perlindungan serta pendampingan pada setiap tingkat pemeriksaan mulai dari penyidikan,penuntutan, sampai dengan pemeriksaan disetiap pengadilan. (Pasal 59 ayat 2 huruf $\mathrm{j}$ UU Perlindungan Anak).

\section{Pengajuan dan Pemberian} Restitusi Bagi Anak Yang Menjadi Korban Kekerasan Seksual pada Anak Berdasarkan PP Nomor 43 Tahun 2017 Tentang Pelaksanaan Restitusi Bagi Anak Yang Menjadi Korban Tindak Pidana

Secara teoritis dalam hukum pidana, restitusi diartikan sebagi upaya untuk merestorasi kondisi korban kepada situasi sebelum mengalami sejumlah kerugian yang diakibatkan adanya suatu kejahatan yang dialami. (Marcus, 2013 : 60) Hal diatas bekaitan dengan pemenuhan hak anak sebagai upaya perlindungan terhadap korban kejahatan seksual diatur dalam pasal 71 D UU Perlindungan Anak yang menyatakan bahwa korban (anak) berhak mengajukan ke pengadilan berupa hakatas restitusi (ganti rugi) yang menjadi tanggungjawab pelaku kejahatan seksual pada anak. Dimana pengaturan terkait aturan serta mekanisme pengajuan diatur dalam 2 peraturan pelaksana UU Perlindungan Saksi dan Korban serta UU Perlindungan Anak yaitu, PP Nomor 44 Tahun 2008 tentang Pemberian Kompensasi, Restitusi dan Bantuan Kepada Saksi dan Korban (Selanjutnya PP Nomor 44 Tahun 2008 ) dan PP Nomor 43 Tahun 2017 Tentang Pelaksanaan Restitusi Bagi Anak Yang Menjadi Korban Tindak Pidana (Selanjutnya PP Nomor 43 Tahun 2017).

Restitusi merupakan salah satu bentuk upaya perlindungan hukum yang diberikan kepada korban dalam hal ini anak yang menjadi korban tindak pidana. Bentuk ganti kerugian ini dirasa perlu disebabkan pemenuhan restitusi bagi anak selama ini tidak hanya menjadi isu kajian nasional namun, juga sebagai bahan kajian internasional. Hal tersebut jelas dengan dikeluarkannya deklarasi PBB di Milan, Italia pada September 1985 yang berbentuk Declaration of Basic Principle of Justice for Victims of Crime and 
Abuse of Power sebagai hasil dari The severnt United Nations Congress on the Treatments of Offenders dengan hasil rumusan mengenai bentuk-bentuk perlindungan yang dapat diberikan terhadap korban seperti,; (Rena Yulia, 2010 : 58) i. Acces to jusctice and fair treatment (akses ke pengadilan serta mendapatkan keadilan) ;ii. Restitution ( restitusi/gantirugi); iii. Compensation (kompensasi) and ; iv. Assistance (perbantuan).

Pelaksanaan Restitusi yang dimaksud dalam pengertian secara definitif harus sesuai dengan Prinsip Pemulihan dalam Keadaan Semula (restutio in integrum), sebab hal tersebut merupakan suatu upaya yang dapat dilakukan bahwa korban kejahatan haruslah dikembalikan pada kondisi semula sebelum kejahatan terjadi meski didasari bahwa tidak akan mungkin korban kembali pada kondisi pada saat sebelum mengalami kerugian yang diderita. Prinsip ini pun menegaskan bahwa bentuk pemulihan yang hendak dilakukan kepada korban haruslah mencapai suatu kelengkapan dalam pemulihan dan mencakup berbagai aspek yang ditimbulkan dari akibat kejahatan. Melalui pengajuan restitusi, maka korban dapat dipulihkan kebebasan, hak-hak hukum, status sosial, kehidupan keluarga dan kewarganegaraan, kembali ke tempat tinggalnya, pemulihan pekerjaannya, serta dipulihkan asetnya. Dalam praktik hampir di banyak negara konsep restitusi ini dikembangkan dan diberikan pula kepada korban kejahatan atas penderitaan mereka sebagai korban tindak pidana. Dalam konsep ini maka korban dan keluarganya harus mendapatkan ganti kerugian yang adil dan tepat dari orang yang telah dinyatakan bersalah atau pihak ketiga yang bertanggungjawab atau pihak keluarga. Ganti kerugian meliputi pengembalian harta milik atau pembayaran atas kerusakan atau kerugian yang diderita, penggantian biaya-biaya yang timbul sebagai akibat jatuhnya korban seperti halnya biaya berobat dan penyediaan jasa dan hak-hak pemulihan. (Supriyadi Widodo E ; 16).

Masalah utama dalam mengupayakan perlindungan 
terhadap anak sangat kompleks termasuk keterbatasan keluarga dalam memahami serta mendapatkan informasi mengenai hak-hak anak serta parenting skills selama proses pemulihan terhadap anak yang menjadi korban. Disamping itu, Masyarakat secara umum juga belum benar-benar memahami prosedur serta mekanisme pengaduan dan rujukan sosial serta mengajukan hak restitusi bagi anak. Akibatnya sangat rentan terjadinya pembiaran terhadap anak pasca terjadinya suatu kejahatan tersebut diterima oleh anak. Penanganan secara khusus bagi anak yang menjadi korban kekerasan seksual merupakan kejahatan yang memiliki dampak serius terhadap psikis, fisik dan lingkungan sosial. Hal ini tentu menjadi hambatan bagi penegak hukum terkait pengungkapan kejahatan seksual disebabkan keluarga korban tidak menghendaki pelaporan, malu, tidak meyakini penuh proses penegakan hukum, kurangnya akses serta lemahnya saksi dan alat bukti dalam kejahatan seksual pada anak. (Erlinda, 2016 )
Disahkannya PP Nomor 43 Tahun 2017 merupakan salah satu bentuk kepedulian pemerintah Indonesia yang diwakili oleh kementrian Pemberdayaan Perempuan dan Perlindungan Anak bersama-sama dengan Seketaris Negara, Kementrian Hukum dan HAM , Kepolisian dan Kejaksaan Agung menginisiasi melalui pembahasan rancangan peraturan pemerintah (RPP) terkait upaya mengurangi beban dari pihak korban atas kerugian materiil dan immateriil yang diterima oleh korban maupun kelurga korban. Regulasi ini merupakan peraturan pelaksana dari Pasal 71 huruf D ayat (2) UU Perlindungan Anak untuk memperjelas mekanisme dan prosedur pemberian serta permohonan hak restitusi bagi anak yang menjadi korban tindak pidana. (Kemenpppa.go.id, 2017)

Konstruksi dalam PP a quo ini menekankan adanya aturan mengenai ganti rugi untuk proses pemulihan bagi anak yang menjadi korban tindak pidana terutama kekerasan seksual. Selama ini, Pemerintah cenderung tidak memperhatikan 
proses pemenuhan hak restitusi dalam bentuk ganti rugi yang diberikan oleh pelaku terhadap korban sebagai bentuk tanggungjawab atas penderitaan yang dialamai anak. Melalui regulasi ini dapat mempermudah anak yang menjadi korban tindak pidana untuk mengajukan hak restitusi kepada pengadilan yang menjadi tanggung jawab pelaku kejahatan. Pengaturan secara khusus dalam bentuk PP ini sebagai wujud perlindungan yang maksimal terhadap korban serta literasi bagi para penegak hukum untuk lebih memiliki perhatian terhadap perlindungan anak pasca terjadinya tindak pidana. Dalam beberapa penelitian mengenai perlindungan anak mengesankan bahwa perlindungan lebih difokuskan kepada anak (korban) sebelum terjadinya tindak pidana sebagai upaya preventif dan penerapan hukumnya melalui upaya represif. Namun, pemerintah serta penegak hukum dan lembaga perlindungan anak cenderung mengabaikan upaya pemenuhan hakhak serta perlindungan secara psikis, mental terhadap anak.
Terminologi ganti rugi dalam pelaksanaan restitusi tidak akan lepas dari pembahasan mengenai fungsi adanya ganti rugi dalam KUHAP yang diatur dalam pasal 98 ayat (1), disebutkan bahwa jika suatu perbuatan yang menjadi dasar dakwaan di dalam suatu pemeriksaan perkara pidana oleh pengadilan negeri menimbulkan kerugian bagi orang lain, maka hakim ketua sidang atas permintaan orang tersebut dapat menetapakan untuk menggabungkan perkara gugatan ganti kerugian kepada perkara pidana tersebut. Namun, pengaturan dalam KUHAP masih terdapat beberapa kekurangan mengenai prosedur pengajuannya yang tidak sederhana disebabkan permohonan ganti kerugian (restitusi) hanya dapat dilakukan melalui gugatan ganti kerugian yang digabungkan dengan pemeriksaan pokok perkara pidana tersebut. Disamping itu, dalam pelaksanaannya melalui mekanisme ini adalah keharusan bagi korban yang menjadi tindak pidana untuk lebih aktif berhubungan dengan penegak hukum terkait proses pengajuan ganti kerugian secara 
materiil yang dalam tugasnya tersebut penuntut umum mengakomodasi kebutuhan hak ganti rugi di muka persidangan. Namun, apabila permohonan ganti kerugian immateriil diajukan oleh korban, kemudian hakim menyatakan gugatan tersebut tidak diterima (niet on valijeke). (Fauzy Marasabessy, $2009: 57)$.

Menurut Muladi dalam konsep pengaturan terhadap perlindungan korban tindak pidana terutama anak yang menjadi korban kejahatan seksual, hal pertama yang harus diperhatikan yakni esensi kerugian yang diderita korban. Esensi kerugian tersebut tidak hanya bersifat materiil atau penderitaan fisik saja tetapi juga yang bersifat psikologis.

Baik dalam bentuk "trauma kehilangan kepercayaan terhadap masyarakat dan ketertiban umum". Simptom dari sindrom tersebut dapat berupa kegelisahan, rasa curiga, sinisme, depresi, kesepian dan perilaku penghindaran lainnya. ( Muladi, 2002 ;177)

Permohonan hak restitusi bagi korban, terdapat dua peraturan pelaksana yang mengatur terkait mekanisme permohonan hak restitusi bagi korban tindak pidana yang diatur dalam PP Nomor 44 Tahun 2008, Restitusi berdasarkan PP Nomr 44 tahun 2008 diartikan bahwa restitusi merupakan ganti kerugian yang diberikan kepada korban atau keluarganya oleh pelaku atau pihak ketiga, dapat berupa pengembalian harta milik, pembayaran ganti kerugian untuk kehilangan atau bentuk penderitaan, atau penggantian biaya untuk tindakan tertentu. Bantuan adalah layanan yang diberikan kepada korban dan/atau saksi oleh LPSK dalam bentuk bantuan medis dan bantuan rehabilitasi psiko-sosial. Sedangkan dalam PP Nomor 43 Tahun 2017 mengartikan restitusi yaitu suatu pembayaran ganti kerugian yang dibebankan kepada pelaku berdasarkan putusan pengadilan yang berkekuatan hukum tetap atas kerugian materiil dan immateriil yang diderita korban atau ahli warisnya, namun PP Nomor 43 Tahun 2017 lebih khusus mengatur terkait pelaksanaan restitusi bagi anak yang menjadi korban tindak pidana. 
Pengajuan permohonan hak restitusi sekurang-kurangnya wajib memuat :

a) identitas pemohon;

b) uraian tentang tindak pidana;

c) identitas pelaku tindak pidana;

d) uraian kerugian yang nyatanyata diderita; dan

e) bentuk Restitusi yang diminta Selain itu juga, pengajuan restitusi juga melampirkan beberapa dokumen pelengkap sebagai syarat dalam pengajuannya sebagai berikut:

f) fotokopi identitas Korban yang disahkan oleh pejabat yang berwenang;

g) bukti kerugian yang nyata-nyata diderita oleh Korban atau Keluarga yang dibuat atau disahkan oleh pejabat yang berwenang;

h) bukti biaya yang dikeluarkan selama perawatan dan/atau pengobatan yang disahkan oleh instansi atau pihak yang melakukan perawatan atau pengobatan;

i) fotokopi surat kematian dalam hal Korban meninggal dunia; j) surat keterangan dari Kepolisian Negara Republik Indonesia yang menunjukkan pemohon sebagai Korban tindak pidana;

k) surat keterangan hubungan Keluarga, apabila permohonan diajukan oleh Keluarga; dan

1) surat kuasa khusus, apabila permohonan Restitusi diajukan oleh kuasa Korban atau kuasa Keluarga. (ICJR, 2017; 42).

Dalam hal pemenuhan hak restitusi ini, LPSK merupakan lembaga yang diberi tugas sekaligus wewenang dalam PP ini untuk memberikan perlindungan dan hakhak lain seperti restitusi kepada saksi dan atau korban sesuai dengan ketentuan yang telah diatur dalam peraturan-perundang-undangan.

Demikian pula dalam permohonan restitusi mengenai tatacara pengajuan yang dapat mengajukan hak restitusinya berdasarkan pasal 2 angka 2 adalah (i). Anak yang behadapan dengan hukum,

(ii). anak yang dieksploitasi secara ekonomi dan atau seksual,;

(iii). Anak yang menjadi korban pornografi,; 
(iv). Anak korban penculikan, penjualan, dan atau perdagangan.; (v). Anak korban kekerasan fisik dan atau psikis;

(vi). serta Anak korban kejahatan seksual.

Perlu dipahami bahwa konstruksi pelaksanaan yang diatur dalam restitusi sebagai wujud ganti rugi kepada korban atas perbuatan pelaku yang merugikan berbeda dengan restitusi secara definitive pada umumnya. Ganti kerugian yang dimaksud dalam PP tersebut merupakan ganti kerugian atas kehilangan kekayaan; ganti kerugian atas penderitaan sebagai akibat tindak pidana; dan atau penggantian biaya perawatan medis dan atau psikologis yang diderita oleh anak yang menjadi korban tindak pidana.

Permohonan restitusi wajib diajukan oleh pihak korban, seperti orang tua atau wali anak yang menjadi korban tindak pidana, ahli waris anak yang menjadi korban tindak pidana, seseorang yang telah diberi kuasa oleh orang tua, wali atau ahli waris anak dengan surat kuasa khusus dan pihak yang dapat diberi kuasa adalah lembaga bantuan hukum dan lembaga yang menangani perlindungan anak yaitu LPSK.

Sebelum mengajukan permohonan restitusi kepada pengadilan, maka terlebih dahulu diingat bahwa pengajuan harus diajukan secara tertulis dalam bahasa Indonesia diatas kertas dengan dibubuhi materai serta diajukan sebelum putusan pengadilan yakni ditahap penyidikan dan penuntutan. Namun, dalam tahap penyidikan, penyidik dapat memberitahukan kepada pihak korban mengenai hak anak yang menjadi korban tindak pidana untuk mendapatkan restitusi dan tata cara pengajuannya. Atas pemberitahuan ini, pihak korban memiliki waktu paling lama tiga hari untuk mengajukan permohonan restitusi.

Kemudian, penyidik memeriksa kelengkapan berkas permohonan paling lama tujuh hari sejak tanggal diterimanya pengajuan permohonan. Jika ada kekurang lengkapan permohonan penyidik memberitahukan kepada pemohon agar dilengkapi.

Waktu bagi pemohon melengkapi permohonan adalah tiga 
hari sejak diterimanya pemberitahuan tersebut. Jika tak dilengkapi, maka pemohon dianggap belum mengajukan permohonan. Penyidik dapat meminta penilaian besaran permohonan restitusi yang diajukan. apabila permohonan restitusi pemohon dinyatakan lengkap. atau, LPSK menyampaikan hasil penilaian besaran permohonan restitusi berdasarkan dokumen yang disampaikan penyidik paling lama tujuh hari setelah permohonan penilaian restitusi diterima. Kemudian, permohonan restitusi yang dinyatakan lengkap sesuai dengan syarat-syarat yang ditentukan saat proses pengajuan restitusi tersebut kemudian dikirim penyidik dengan dilampirkan dalam berkas perkara kepada jaksa penuntut umum. (Hukum Online, 2017)

Ketentuan pemberian hak restitusi bagi anak yang menjadi korban tindak pidana dalam PP No. 43/2017 sangatlah dibutuhkan untuk membantu pembiayaan pemulihan korban anak dan memberikan keadilan (restorative justice) bagi korban anak atas tindakan pelaku kejahatan seksual. Disamping itu, ketentuan dalam PP No. 43/2017 ini menegaskan adanya tanggungjawab pelaku terhadap korban yang disebabkan oleh tindakan yang telah dilakukan. Namun, jika dilihat secara komprehensif mengenai PP No. 43/2017 tersebut, terdapat beberapa hal yang tidak jelas, apabila pelaku tindak pidana kejahatan seksual menolak membayar restitusi (biaya ganti rugi). Beberapa persoalan lainnya dalam PP No. 43/2017 adalah bagaimana pembuktian kerugian nilai materiil yang dimiliki oleh korban, sehingga dapat terjadinya ketidakpastian akan proses penjatuhan jumlah besaran yang tidak dapat diprakirakan akibat kerugian yang diderita. Selain itu, mengenai batas waktu pemberian restitusi dari pihak pelaku terhadap korban, hal ini berpengaruh kepada proses pemulihan korban anak.

\section{Simpulan}

Pada dasarnya prosedur pengajuan serta pemberian ganti rugi kepada anak yang menjadi korban tindak pidana kekerasan seksual telah diatur dalam KUHAP, UU Perlindungan Saksi dan Korban, UU 
Perlindungan Anak, selain itu, lainnya setelah pengajuan restitusi pengaturan teknis mengenai diterima yang mengakibatkan pengajuan dan pemberian restitusi hilangnya suatu upaya seperti bekerja khusunya bagi anak yang menjadi korban tindak pidana diatur dalam PP Nomor 44 Tahun 2008 dan PP Nomor 43 Tahun 2017. Mengenai pengawalan secara serius dalam pelaksanaan restitusi ini dapat memberikan jalan mudah bagi korban tindak pidana kejahatan seksual untuk mendapatkan ganti kerugian yang berupa restitusi dari pelaku tindak pidana kejahatan seksual atas perbuatannya yang mengalami kerugian serta penderitaan yang dialami korban (anak). Namun, hal lain yang menjadi kendala yaitu mengenai terbatasnya jenis dan jumlah kerugian yang dapat dimintakan serta batasan minimal ataupun maksimal, selain itu perlu dikaji kembali bagaimana apabila pelaku menolak untuk membayar restitusi serta batasan (jangka waktu) pembayaran restitusi kepada anak yang menjadi korban tindak pidana. Disamping itu, ada hal yang belum dijelaskan dalam PP tersebut apabila pelaku untuk mengganti kerugian yang dialami korban. Begitupun dengan aspek implementatifnya, Kurangnya sosialisasi yang seharusnya patut dilakukan oleh institusi ataupun lembaga yang berwenang dalam melindungi hak-hak anak mengakibatkan cenderung terjadinya pembiaran oleh keluarga dan ahli waris pasca terjadinya kejahatan tersebut. Disamping itu, banyaknya korban ataupun pihak keluarga yang tidak mengetahui bagaimana proses pengajuan hak restitusi ke pengadilan ketika tahapan-tahapan dalam proses pengajuan dan pemberian restitusi tidak di sosialisasikan secara maksimal terlebih oleh penegak hukum yang bersinggungan secara langsung saat penanganan perkara.

\section{Daftar Pustaka}

\section{Buku}

Lilik Mulyadi, 2010, Kompilasi Hukum Pidana Dalam Prespektif Teoritis dan Praktek Peradilan, Bandung : Mandar Maju. 
Maidin Gultom, 2013, Perlindungan Hukum terhadap Anak dan Perempuan, Bandung : Refika Aditama.

Muladi, 2002,"Hak Asasi Manusia, Politik dan Sistem Peradilan Pidana", Semarang: Badan Penerbit Universitas Diponegoro.

Widiyono, Dkk, 2016, Penanganan Anak Korban ; Pemetaan Layanan Anak Korban di Beberapa Lembaga, Jakarta : Institute for Criminal Justice Reform.

Yulia, Rena. 2010. Viktimologi Perlindungan Hukum Terhadap Korban Kejahatan. Cetakan Pertama. Yogyakarta : Graha Ilmu.

\section{Jurnal}

Alvianto. R.V. Ransun, 2012, Mekanisme Pemberian Kompensasi Dan Restitusi Bagi Korban Tindak Pidana, Lex Crimen Volume 1, Fakultas Hukum Universitas Sam Ratulangi.

Helmy Hakim, Muhammad, 2016, Pergeseran Orientasi Penelitian hokum : Dari Doktrinal ke Socio Legal, IAIN Antasari Banjarmasin.

Marasabesy, Fauzy, 2015, Restitusi Bagi Korban Tindak Pidana : Sebuah Tawaran Mekanisme Baru, Jurnal Hukum dan Pembangunan,
Fakultas Hukum Universitas Indonesia.

Marcus A Asner, 2013, 'Restitution From the Victim Perspective-Recent Developments And Future Trends' Federal Sentencing Reporter.

Renaldi P, Bahewa, 2016 ,Perlindungan Hukum Terhadap Anak Sebagai korban Pelecehan Seksual Menurut Hukum Positif di Indonesia, Lex Administratum Volume IV, Fakultas Hukum Universitas Sam Ratulangi.

Simamarta, Rikardo, 2006, Socio Legal Studies dan Pembaharuan Hukum, Digest Law, Society \& Development.

Sibua YP, Haris, 2017, Persoalan Hukum Atas Restitusi Terhadap Anak Korban Tindak Pidana, Volume IX, Pusat Penelitian dan Badan Keahlian DPR RI.

Wiguno, Ario Ponco 2013, Kajian Viktomologi Terhadap Anak Sebagai Korban Tindak Pidana Kesusilaan, Jurnal Ilmu Hukum Legal Opinion.

Wahyu Ningsih, Sri Endah, 2016, Perlindungan Hukum Terhadap Anak Sebagai korban Tindak Pidana kesusilaan dalam Hukum Pidana Positif Saat Ini., 
Jurnal Pembaharuan Hukum, Volume 3., Fakultas Hukum UNISSULA.Fathan Qorib, 2017,ini poin-poin pp pelaksanaan restitusi bagi anak korban tindak pidana, hukum online(Di akses 18 November 2018)https://www.hukumonl ine.com/berita/baca/lt59eef 5e356c54/ini-poin-poin-pppelaksanaan-restitusi-bagianak-korban-tindak-pidana.

Restitusi Bagi Korban Tindak Pidana (2017) (Di akses 28 November 2018) https://www.kemenpppa.go. id/index.php/page/read/29/1 526/restitusi-bagi-anakkorban-tindak-pidana

\section{Peraturan Perundang-Undangan}

Undang-Undang Nomor 35 Tahun 2014 tentang Perubahan Atas UU Nomor 22 Tahun 2003 Tentang Perlindungan Anak.

Undang-Undang Nomor 31 Tahun 2014 tentang Perubahan atas Undang-Undangan Nomor 13 Tahun 2016 tentang Lembaga Perlindungan Saksi dan Korban.

Peraturan Pemerintah Nomor 44 Tahun 2008 Tentang Pemberian Kompensasi, Restitusi, Dan Bantuan Kepada Saksi Dan Korban.

Peraturan Pemerintah No. 43 Tahun 2017 Tentang Pelaksanaan Restitusi Bagi Anak Yang
Menjadi Korban Tindak Pidana.

Undang-Undang Nomor 10 Tahun 2012 Tentang Pengesahan Optional Protocol To The Convention On The Rights Of The Child On The Sale of Children, Child Prostitution And Child Pornography (Protokol Opsional Konvensi HakHak Anak Mengenai Penjualan Anak, Prostitusi Anak, Dan Pornografi Anak. 